\title{
A radically simple way to monitor
}

life expectancy

EAPS Mortality Workshop 2021

Ilya Kashnitsky, Alexey Raksha, José Manuel Aburto, Jonas Schöley, James Vaupel

22 September 2021 
The current state of the paper

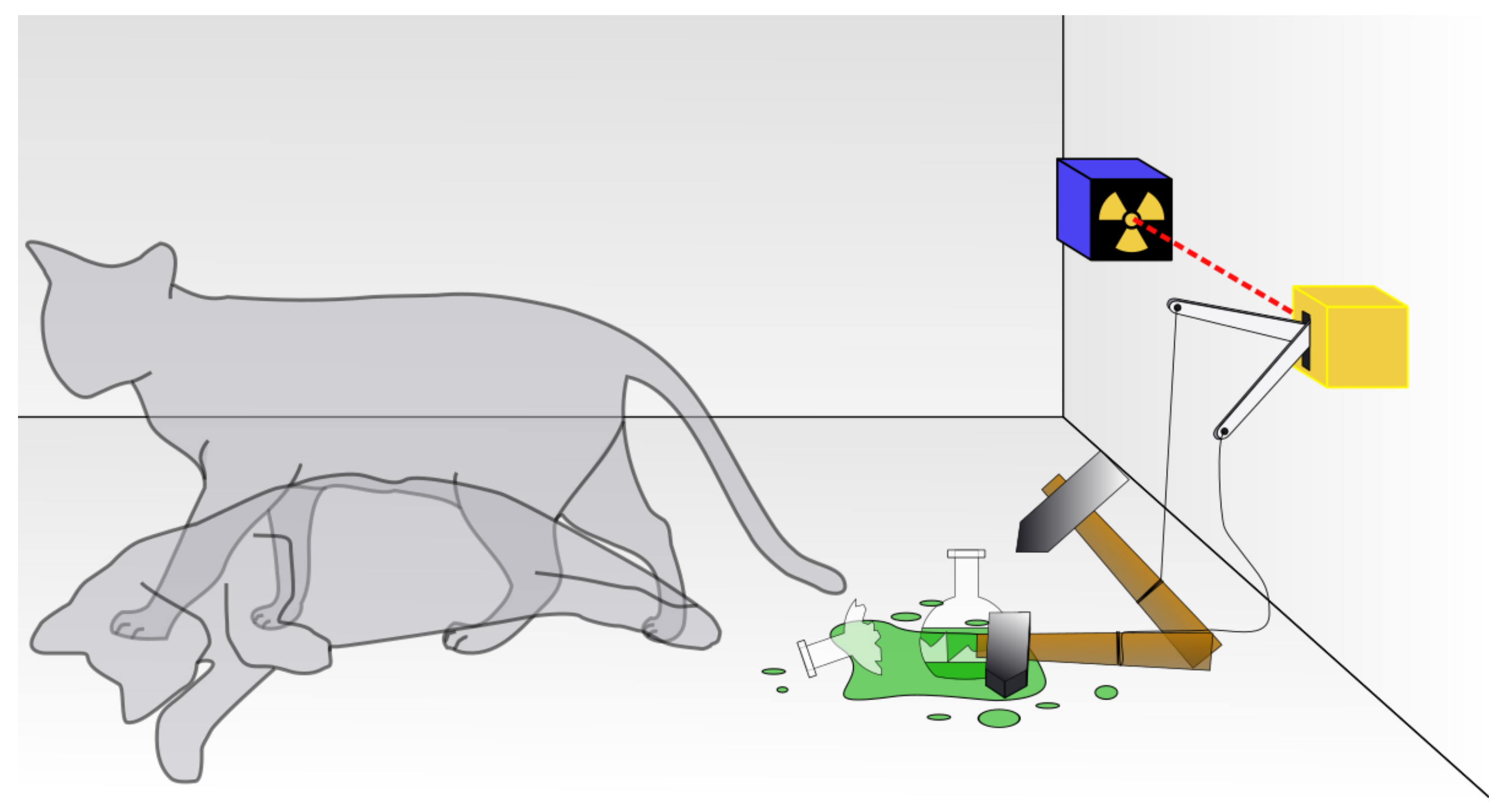




\section{What do I want today?}

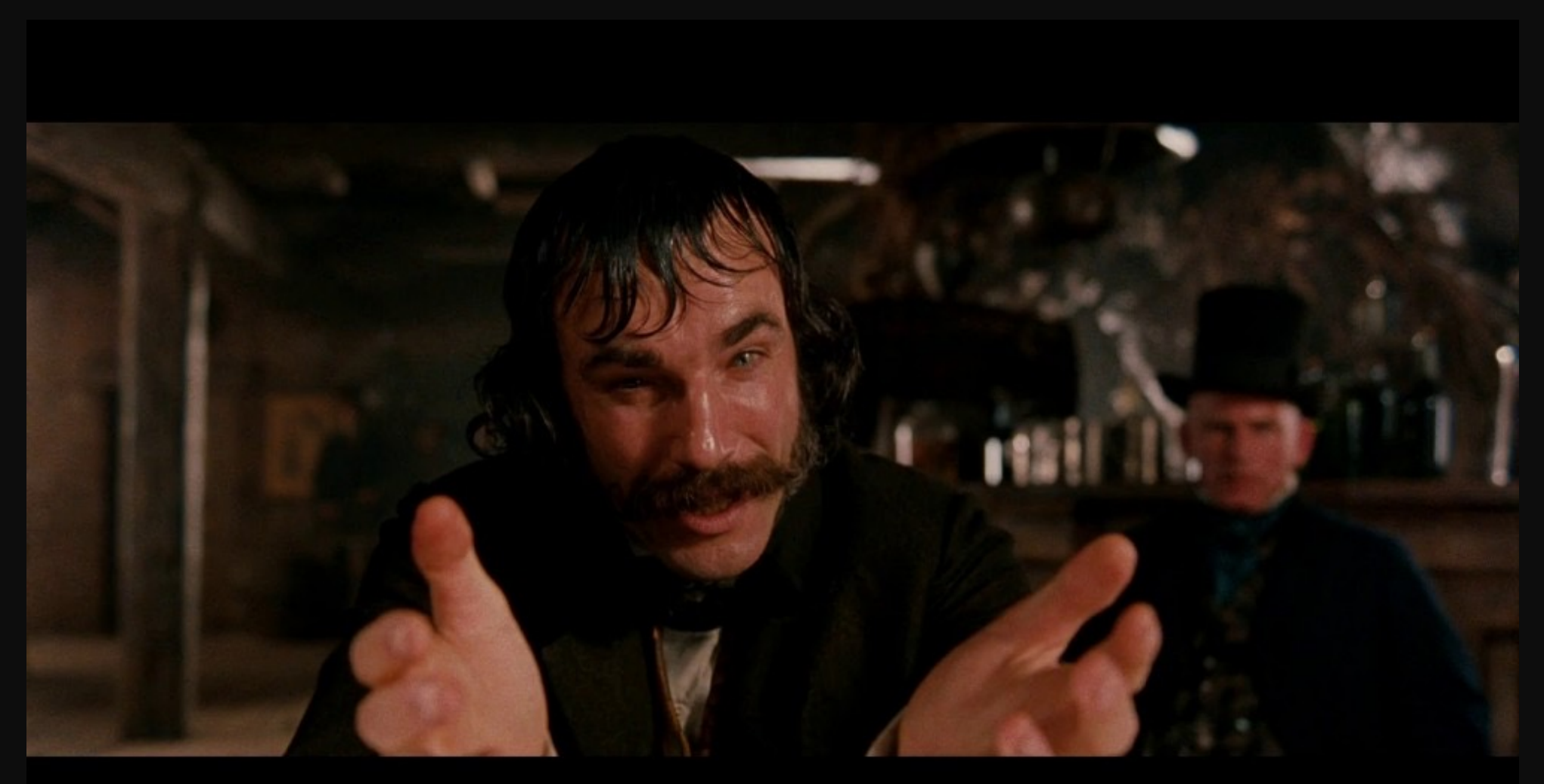




\section{What do I want today?}

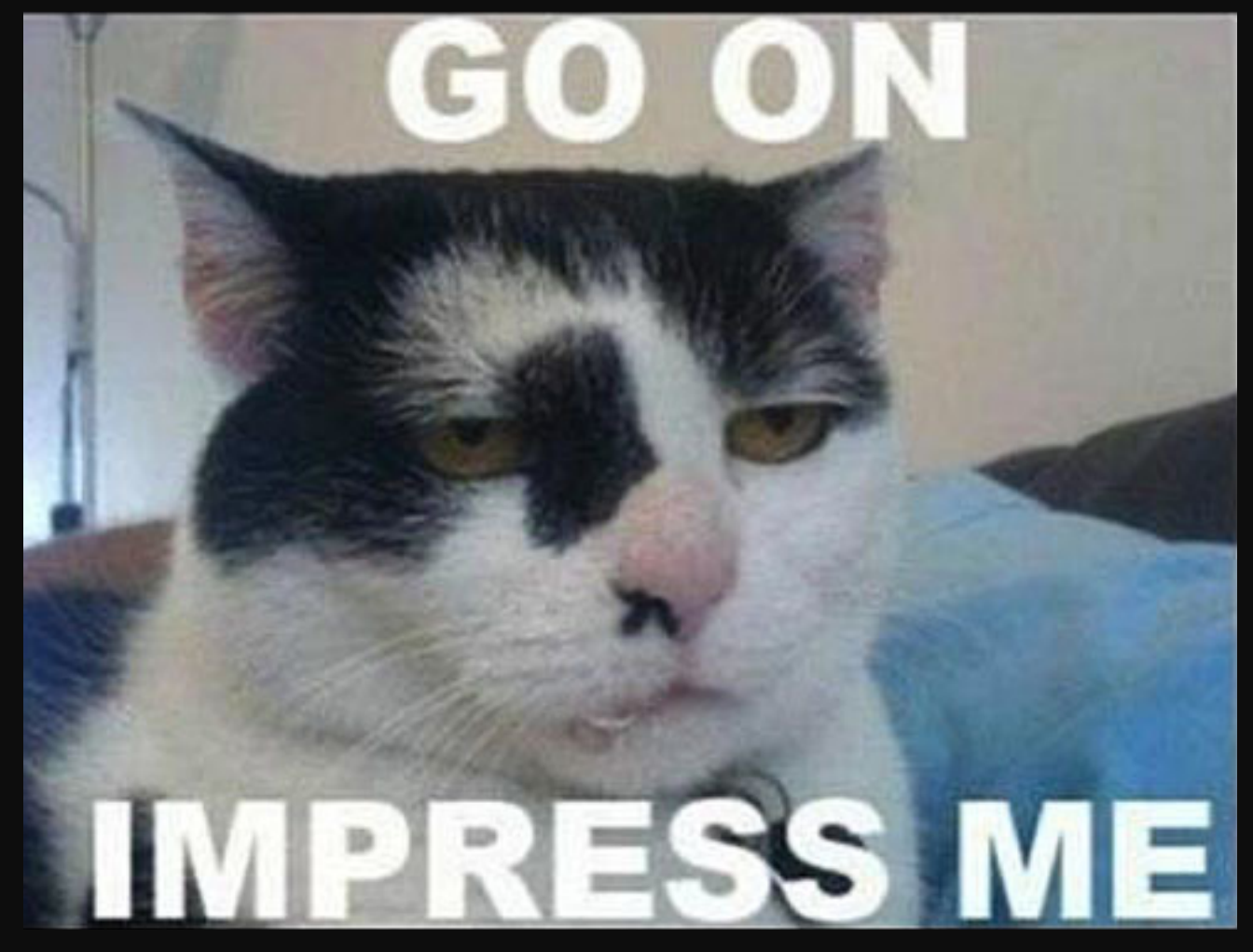




\section{What do I want today?}
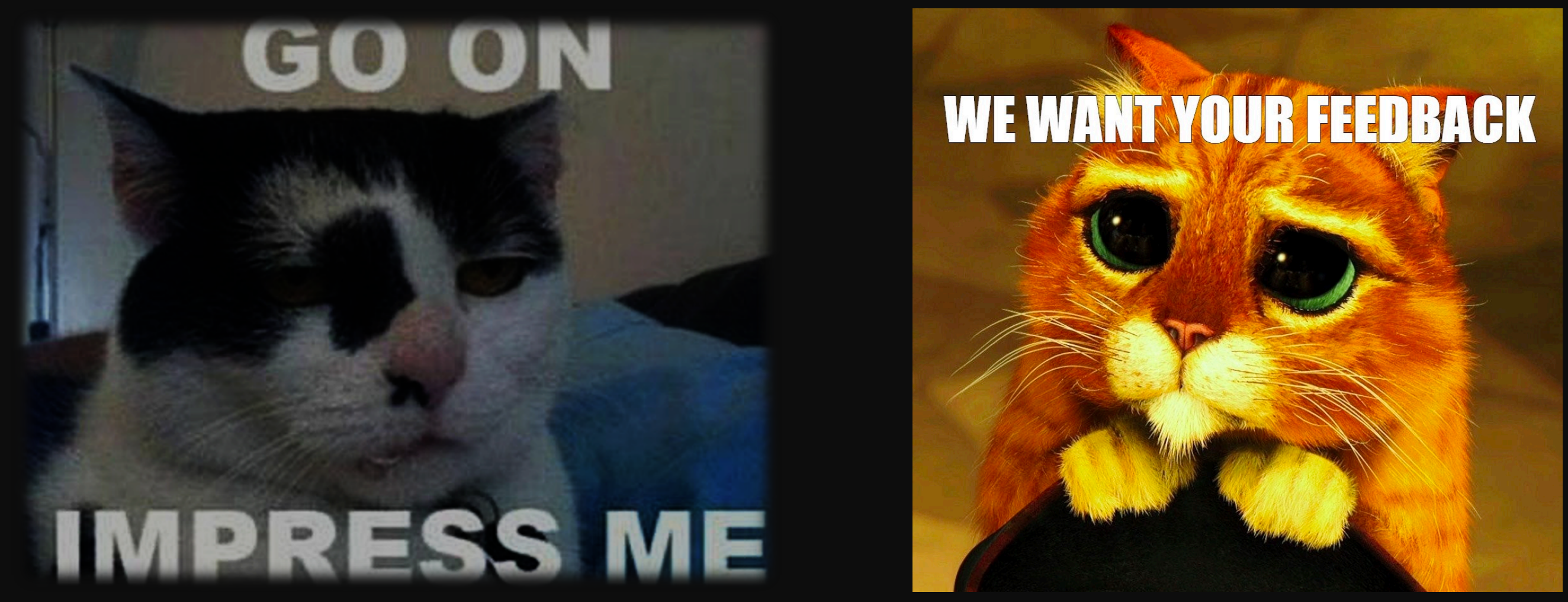
A Russian Demographer Questioned Government COVID-19 Numbers. He Was Fired Earlier This Month.

July 13, 2020 16:24 GMT

By Mark Krutov Timur Olevsky

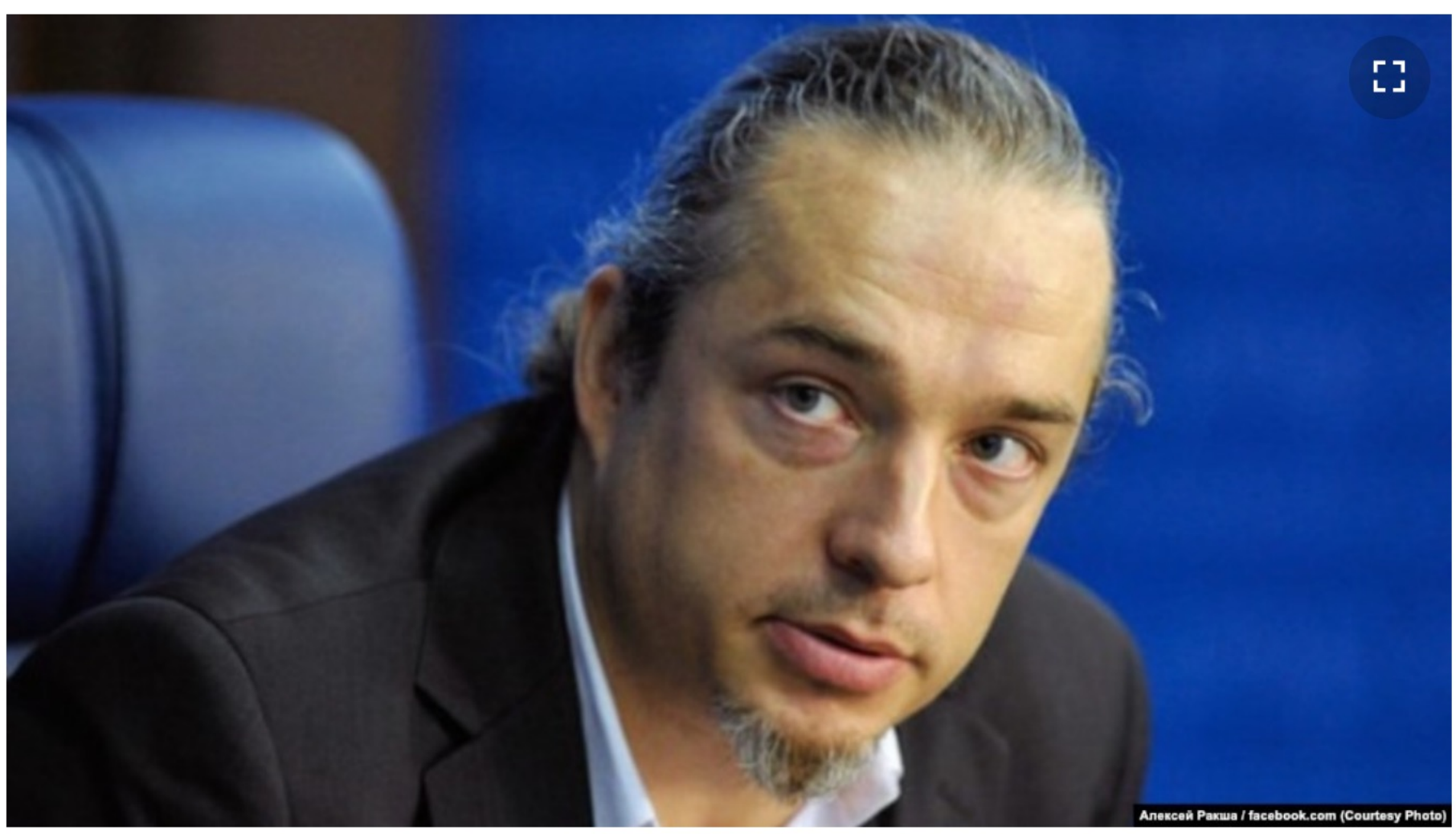

\section{Initial idea}

Alexei Raksha 
Death rates have climbed far above historical averages in many countries that have faced Covid-19 outbreaks

Number of deaths per week from all causes, 2020 vs recent years:

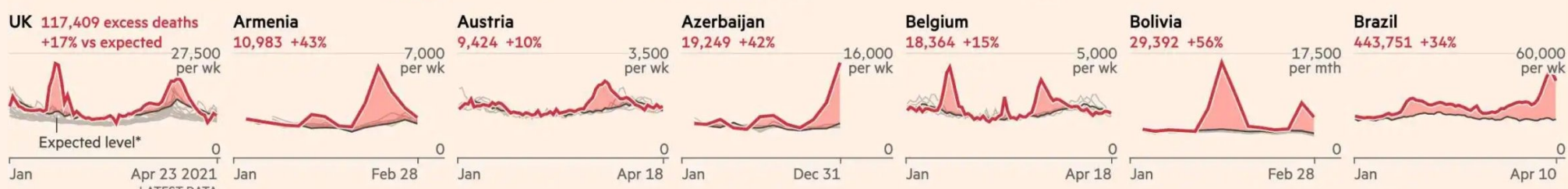

Bulgaria
$28,390+25 \%$

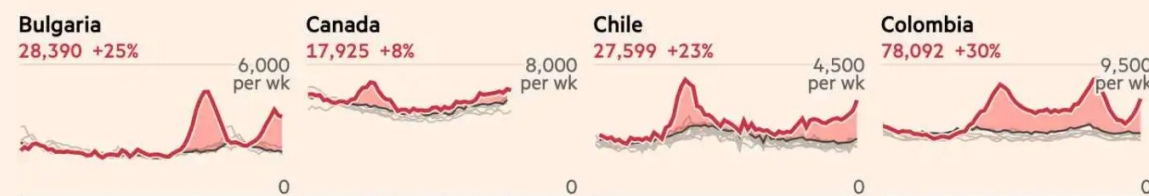

Czech Republic Denmark
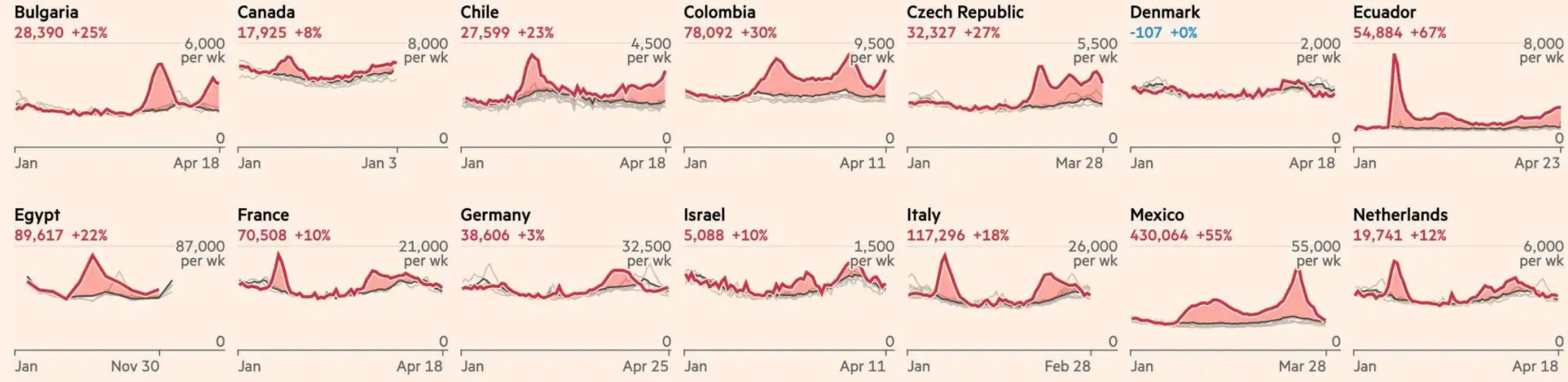

$\stackrel{0}{\text { Apr } 25} \underset{\text { Jan }}{\longrightarrow}$

Apr 11 ำ
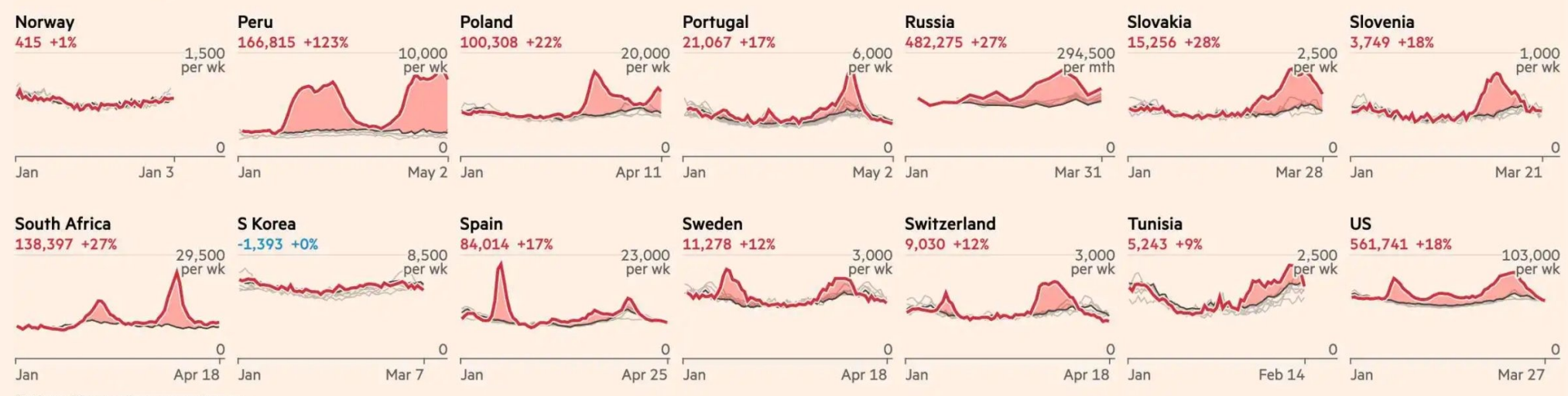

\section{Measuring} the impact of $\mathrm{C} 19$ 


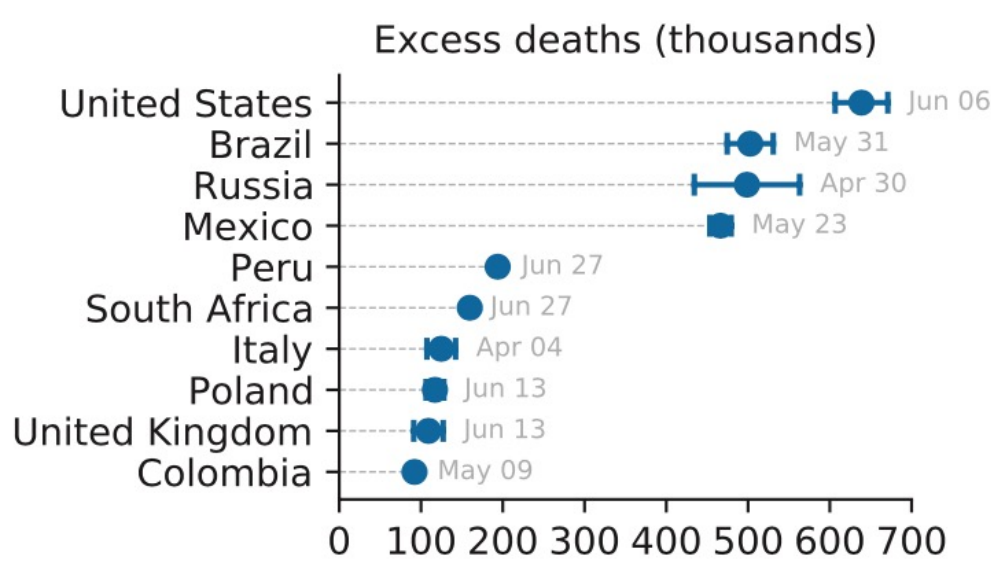

Excess deaths as \% of annual deaths

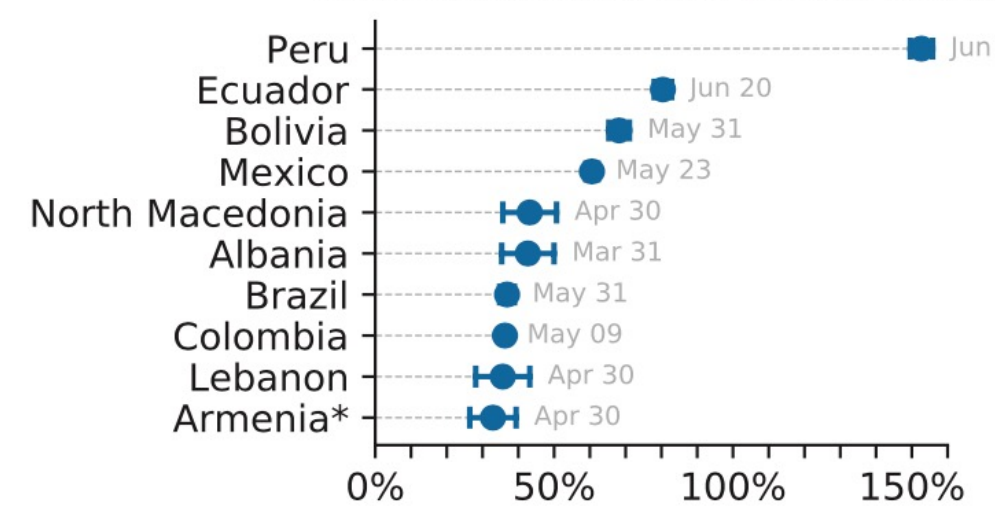

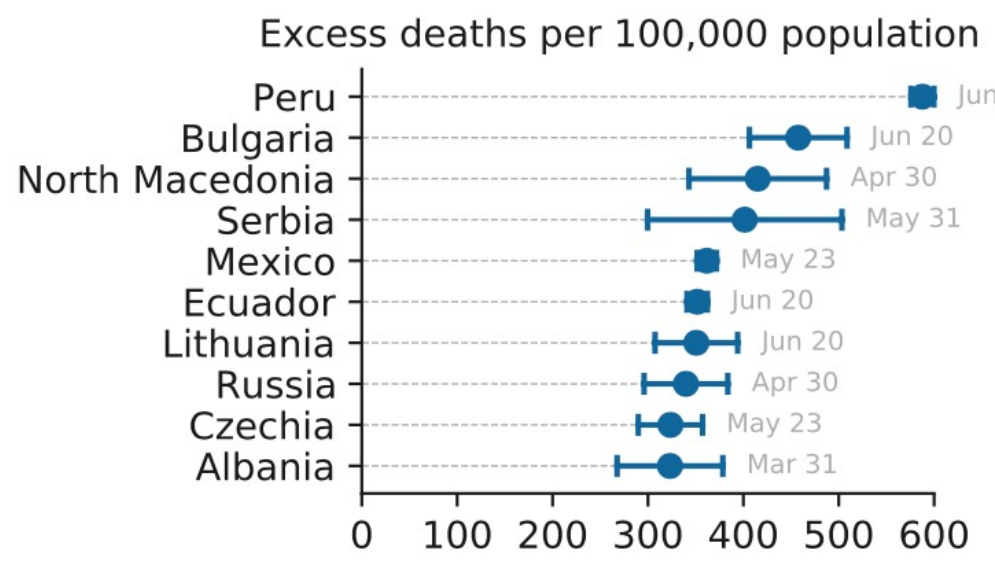

Undercount ratio: excess / official

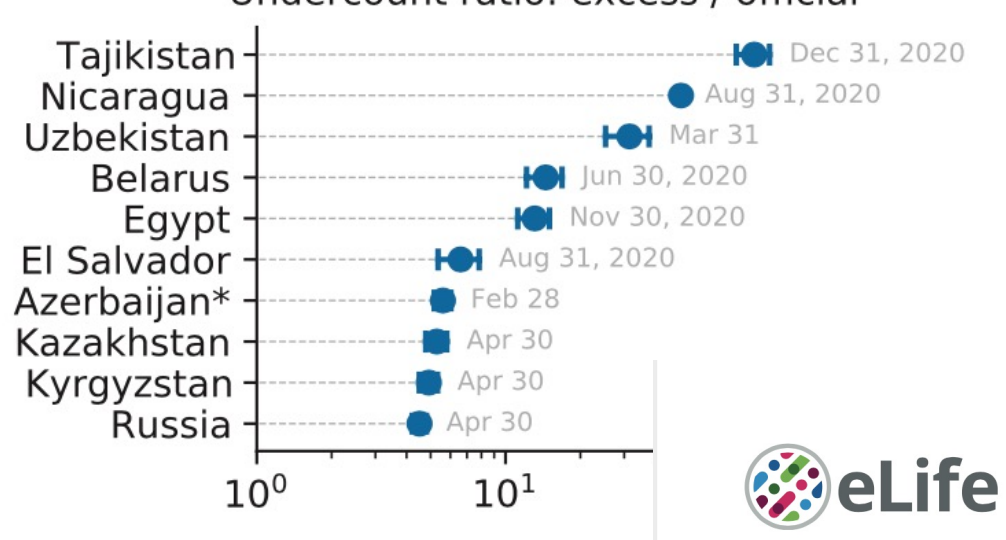

Measuring the impact of $\mathrm{C} 19$

doi.org/10.7554/eLife.69336

TOOLS AND RESOURCES

Tracking excess mortality across countries during the COVID-19 pandemic with the World Mortality Dataset

Ariel Karlinsky ${ }^{1 *}$, Dmitry Kobak ${ }^{2 *}$

${ }^{1}$ Hebrew University, Jerusalem, Israel; ${ }^{2}$ Institute for Ophthalmic Research, University of Tübingen, Tübingen, Germany 
Excess deaths per 100,000 people Central estimate, Jan 2020-present

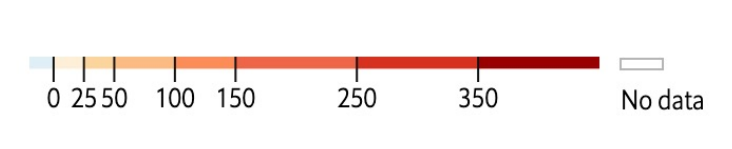

f excess deaths around the world

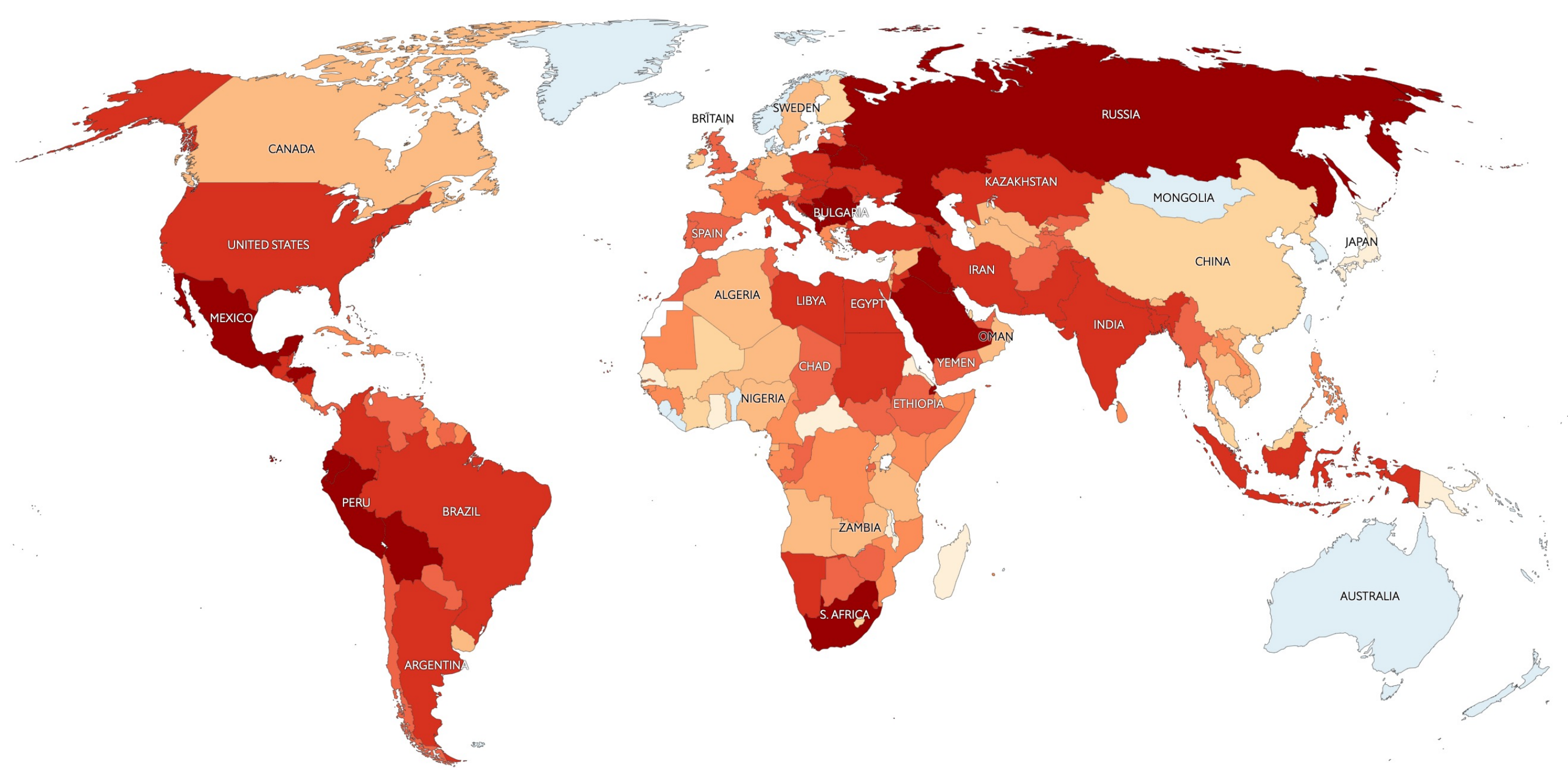




\section{Life expectancy is the ultimate measure of current mortality}

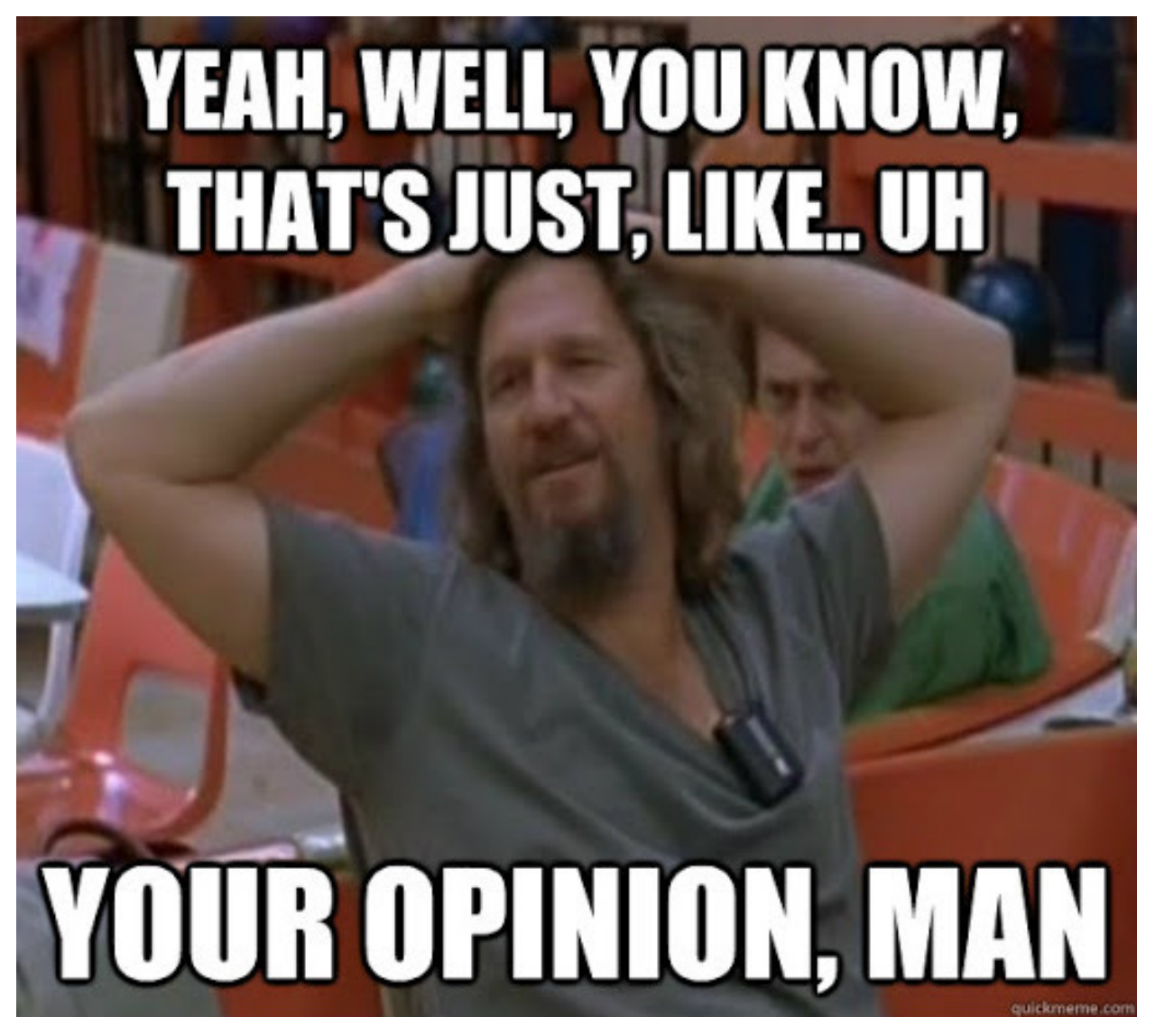




\section{Life expectancy is the ultimate measure of current mortality}

- Free from population age structure effect

- No need to choose standard

- Widely used

4 WHAT IS LIFE EXPECTANCY ?

and (even more important)

$X$ what it isn't $X$

Join in for the most topical demography primer

垔 THREAD $1 / x$

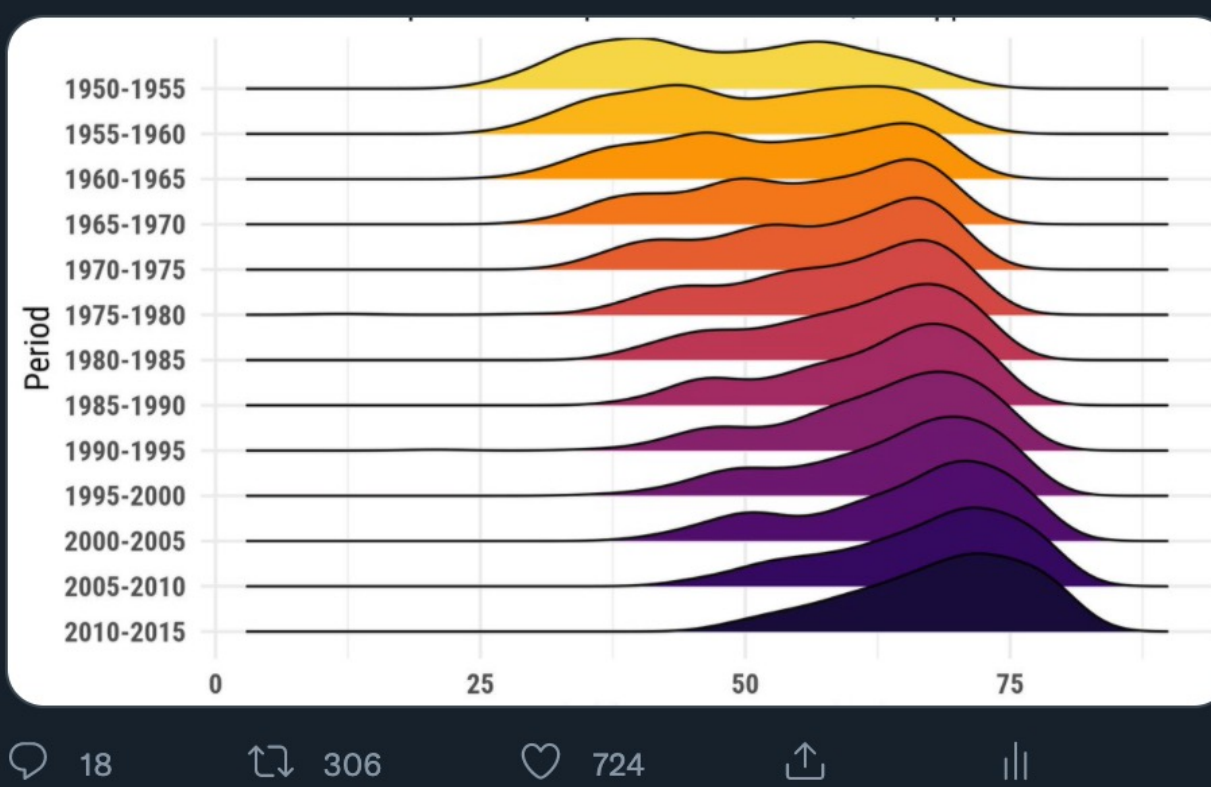

Ilya Kashnitsky

@ikashnitsky

Unlike many statistics and quantities of general use that we tend to see regularly, life expectancy is not observed directly. It's an output of a "mathematical model ${ }^{*}$ called life table. 


\section{Life expectancy is the ultimate measure of current mortality}

- Free from population age structure effect

- No need to choose standard

- Widely used and misunderstood

Life Expectancy: Frequently Used, but Hardly Understood

Marc Luy ${ }^{a, b}$ Paola Di Giulio ${ }^{a, b}$ Vanessa Di Lego ${ }^{a, b}$ Patrick Lazareviča, Markus Sauerberg ${ }^{\mathrm{a}, \mathrm{b}}$

"Wittgenstein Centre for Demography and Global Human Capital (IIASA, VID/ÖAW, WU), Vienna, Austria

Keywords

ects . Heterogeneity

Harvesting effect. Tempo effects

Abstract

Period life expectancy is one of the most used summary all health of a population. Its levels and trends direct health policies, and researchers try to identify velopments. The use of period life expectancy is often based on the assumption that it directly reflects the mortality conditions of a certain year. Accordingly, the explanation for changesinifeexpectary aretypicaly sough in factors that have an imedlate mpact on curen morthy conditions, Iso be affected by at least threekinds of effects in in the situation of short-term fluctuations: cohort effects, heterogeneity effects, and tempo effects. We demonstrate their possible impact with the example of the almost Europe-wide decrease in life expectancy in 2015, which caused a series of reports about an upsurge of a health crisis, and we show that the consideration of these effects can lead to $d$ ferent conclusions. Therefore, wewa toraise an awareness concerning the sensitivity of we expectancy to sudden $\begin{array}{ll}\text { dicator can cause. } & \text { O2019 The Author(s) } \\ & \text { Published bys Karger aG }\end{array}$

\section{Intuction}

Period life expectancy (PLE) is one of the most used summary indicators for the overall health of a population , the number of deaths in a certain year and age roup vided by the average number of people alive in this yea d age group. These death rates are then transformed into probabilities of dying and connected to a survival function from birth to the highest age in which people are living. The mean age at death derived from this survival function is the PLE. It can be interpreted as the average number of years that newborns of a certain period would the undereviling The period perspective must be strictly distinguished Th the cohort perspective. The latter is the mo intuitive and more clearly interpretable analytic concept. It connects the age-specific death rates experienced by a cohort longitudinally over its entire life course. Thus, cohort life expectancy (CLE) reflects the actual mean age at death of real peoplewho were born at the same time. Naturally, CLE can only summarize past mortality experiences, whercas Ple reflects he most current death rates cross-sectionally across all ages. This is why PLE is of frequently used than CLE. 


\section{Life expectancy is the ultimate measure of current mortality}

- Free from population age structure effect

- No need to choose standard

- Widely used and misunderstood

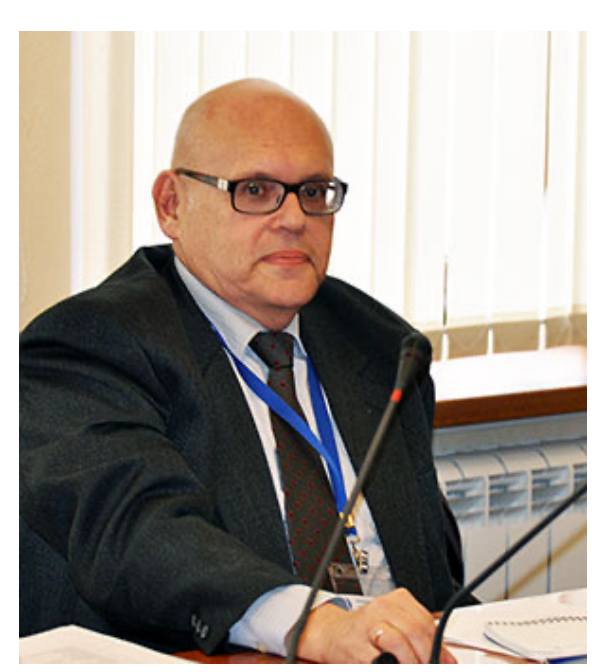

\section{Демографическое обозрение}

\section{электронный научный журнал}

ТЕКУЩИй ВЫПУСК АРХИВЫ ENGLISH SELECTION ABTOPAM - O HAC

ГЛАВНАЯ / АРХИВЫ / ТОМ 8 № 2 (2021) / Оригинальные статьи

Действительно ли ожидаемая продолжительность жизни при рождении является наилучшим измерителем уровня смертности населения?
ДЕЙСТВИТЕЛЬНО ЛИ ОЖИДАЕМАЯ

ПРОДОЛЖИТЕЛЬНОСТЬ ЖИЗНИ ПРИ РОЖДЕНИИ ЯВЛЯЕТСЯ НАИЛУЧШИМ ИЗМЕРИТЕЛЕМ УРОВНЯ СМЕРТНОСТИ НАСЕЛЕНИЯ?

ЕВГЕНИЙ АНДРЕЕВ

Принято считать, что наиболее адекватной характеристикой уровня смертности населения б некоторый период времени является показатель "ожсидаемая продолжительность жизни при рождении» (ОПЖ). Данньй показатель имеет серьезные недостатки, а подобный выбор создает ряд неоправданных трудностей. Главный недостаток - метод расчета ОПЖ до сих пор не унифицирован и, скорее всего, унифицирован быть неможет. В силу этого ОПЖ для разных стран

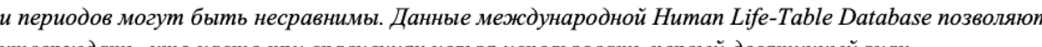
утверэдать, что ч

Определение ОПЖ требует расчета таблии смертности для условного поколения календарного периода. Когда уровень смертности быстро снижкается, как это происходит в больиинстве стран с середины XX века, табличы смертности условного поколения мало что говорят о возрастных закономерностях смертности когорт, но, скорее, формируют ложные впечатления. Подсчет числа человек в условном поколении, которые дожсивают или не доживают до некоторого возраста, не имеет отноиения ни к какой реальной совокупности. Лииь расчет ОПЖ оправдывает построение таблии смертности.

Переход от возрастных показателей смертности к ОПЖ описывается не формулой а вычислительной прочедурой. Это создает серьезные трудности при попытках оуенить влияниен ОПЖ смертности отдельных возрастов, от отдельных причин смерти, в отдельных регионах $и$ группах населения.

Всеми этими недостатками не обладает стандартизованный коэффичиент смертности (СКС), расчет которого становится безальтернативным, как только задано стандартное население.

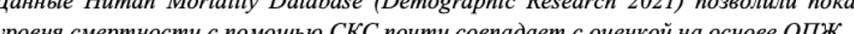

СКС - линейная функция возрастных коэффичиентов смертности, поэтому расчет влияния смертности отдельных возрастов, причин смерти, смертности регионов или групи населения на СКС осуществить несложно.

Непрофессионалы восприниают ОПЖ на ичтуитивнои уровне как длительности чеповечской жизни, что, скорее, недостаток показателя. Использование СКС требует больме обиясчений

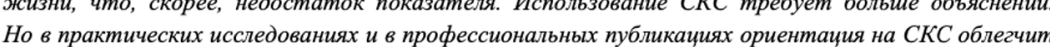
работу и защитит от необоснованных эмочий.

Ключевые слова: смертность, ожсдаемая

коэффициент смертности, уровень смертности

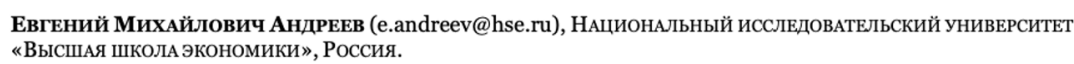

СТАТЬЯ постУПиЛА в РЕДАКЦИю в МАРтв 2021 Г. 


\section{Initial idea}

Life expectancy can be

accurately

approximated with just

its own time series

using a linear model and the change in total death count

World Mortality Dataset - Deaths Across Time in 107 Countries

Purple: 2021, Red: 2020, Grey: 2015 to 2019. Last updated on: 2021-09-21.
Albania Bermuda Bolivia Cuprus French Polynesia Gergia Germany Gibratar Greece Greenand Guadeloupe Guatemala Iran s Ireland Israel Liechtenstein Lithunia Luxembourg Macao Malaysia Mata Martinime Mauritius Mayote Monaco Monolia Montengero Netherands Peru Philipines Poland 1 Portugal Puerto Rico

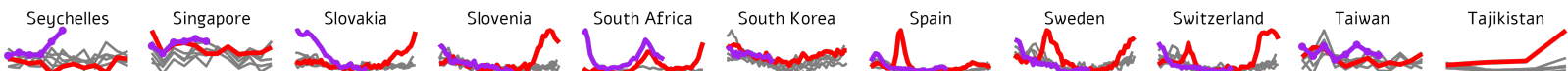

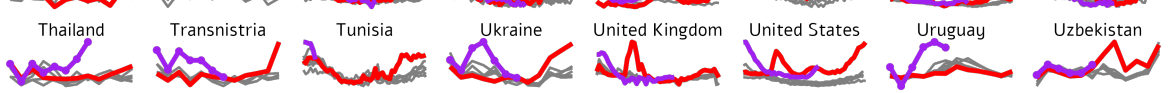

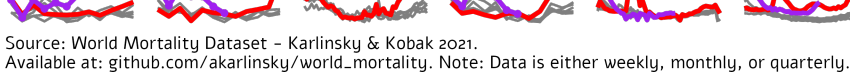




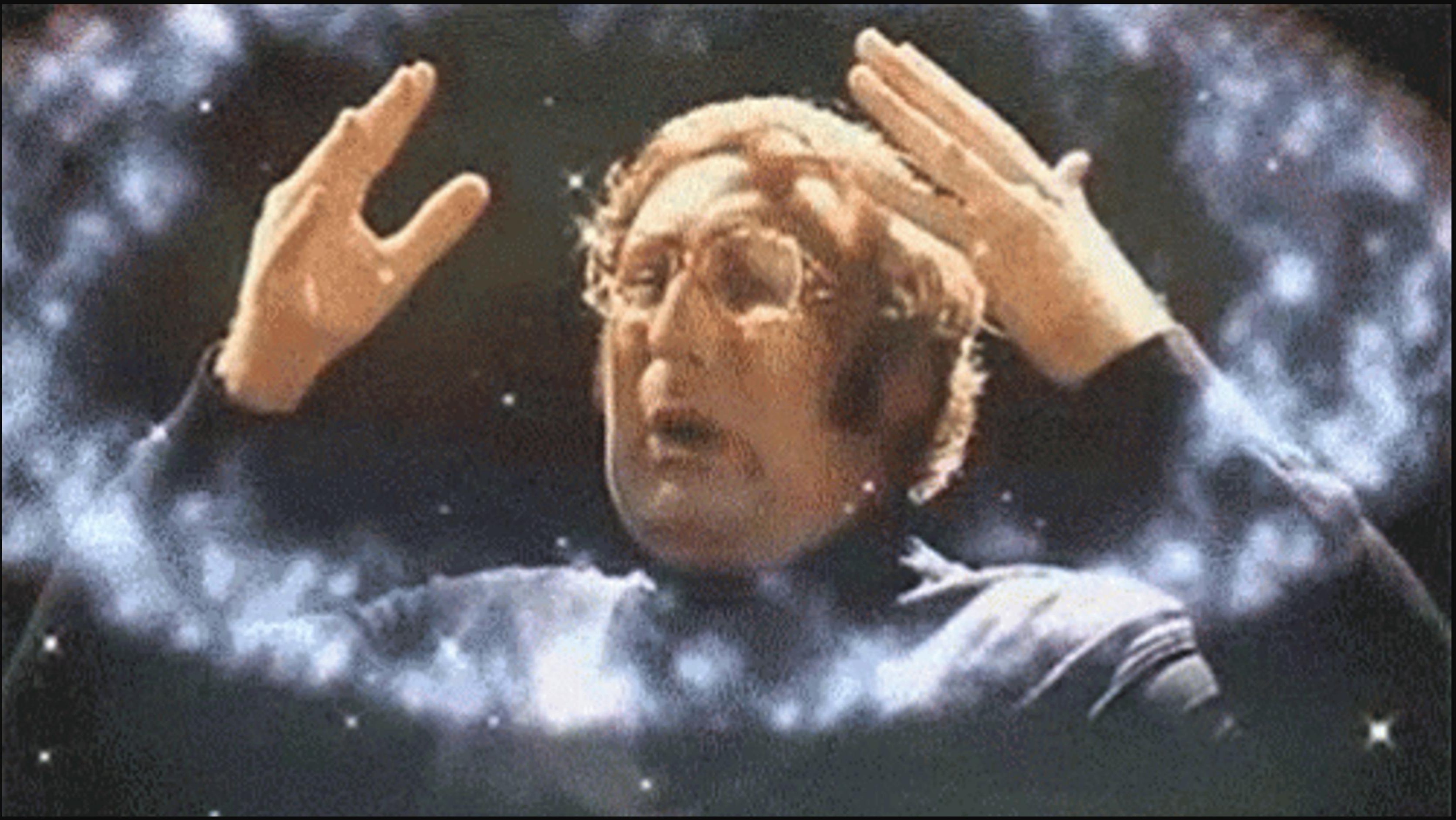




\section{Life expectancy}

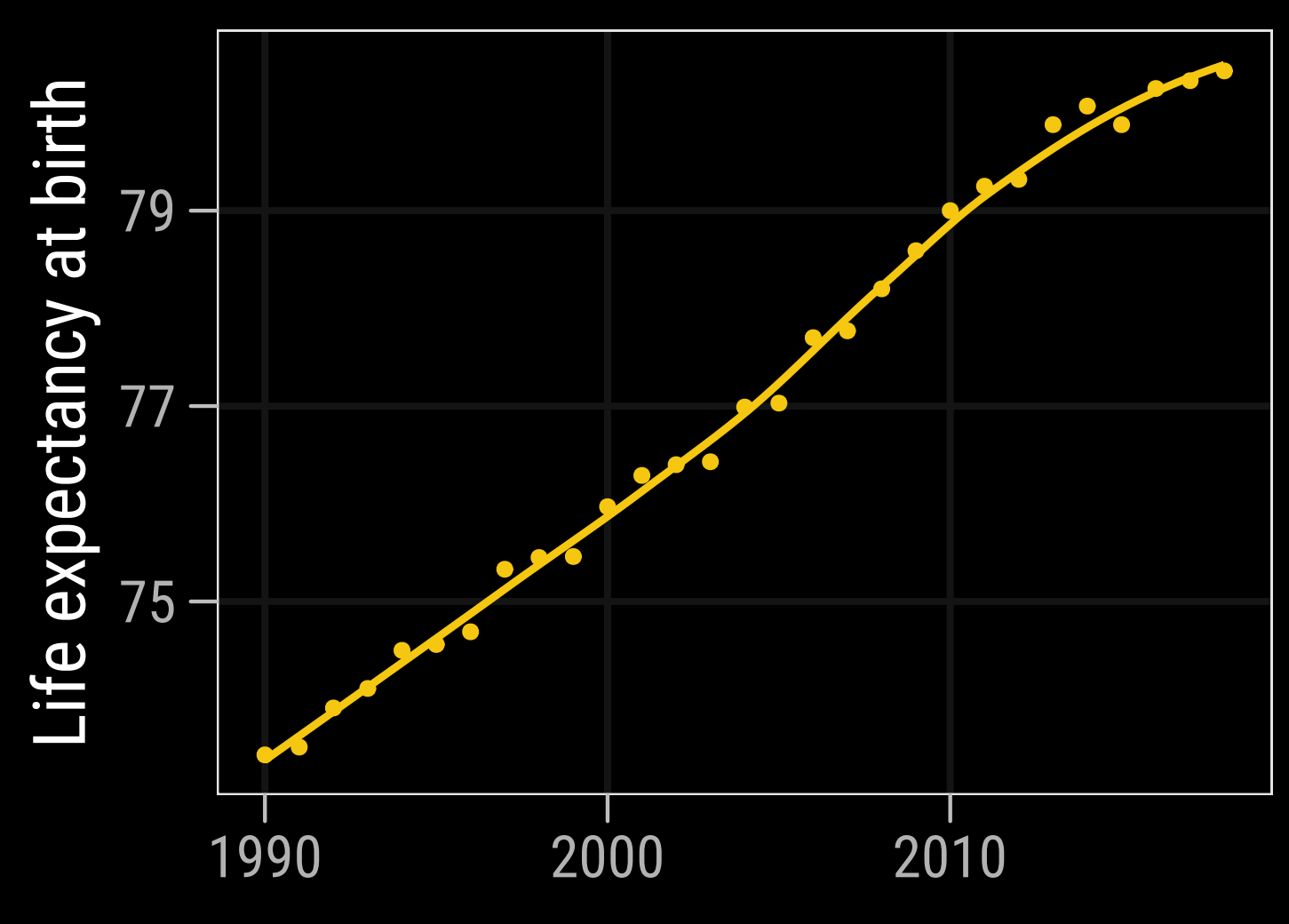

Total death counts

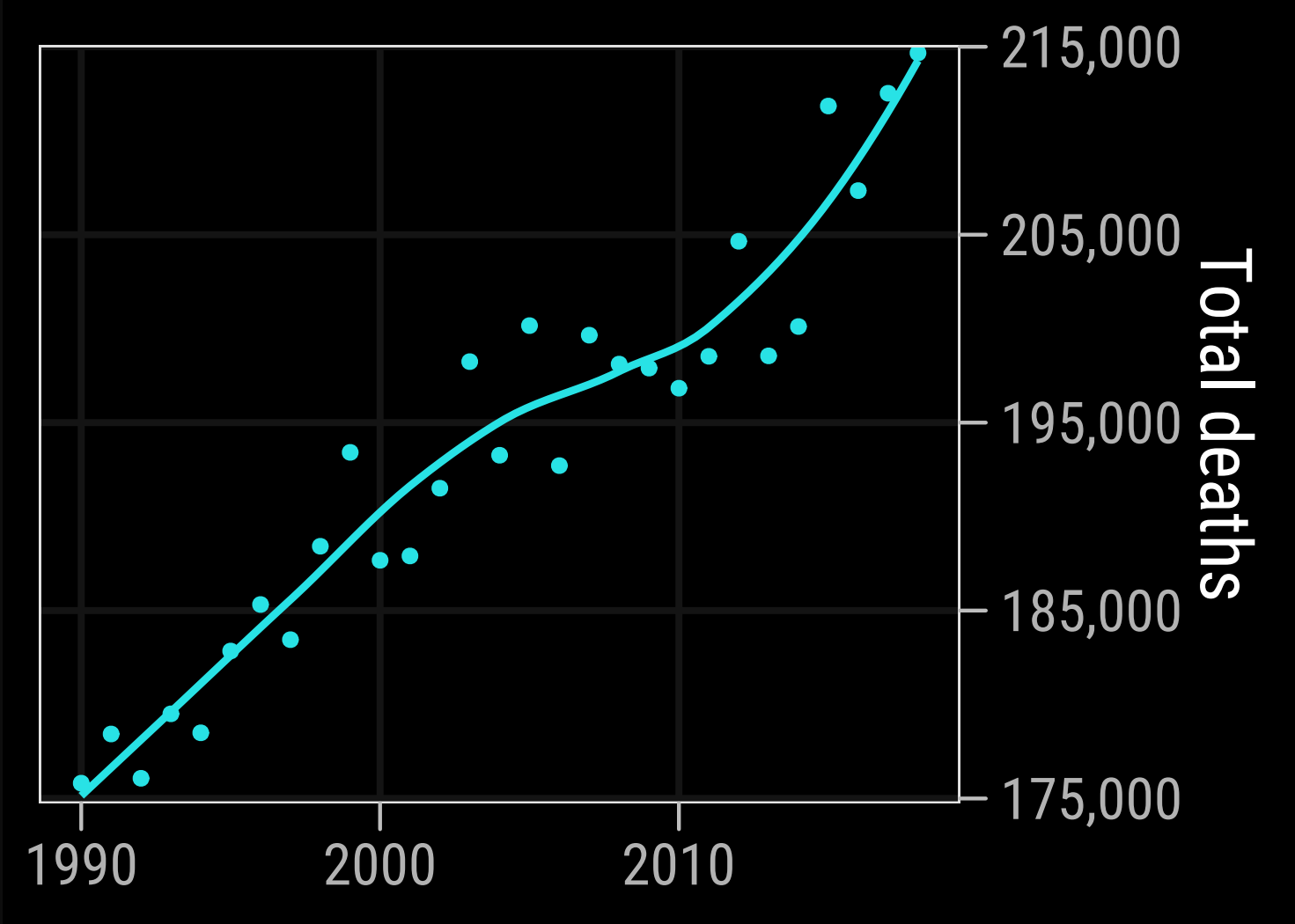

One country example: Spain, males 
Linear fit

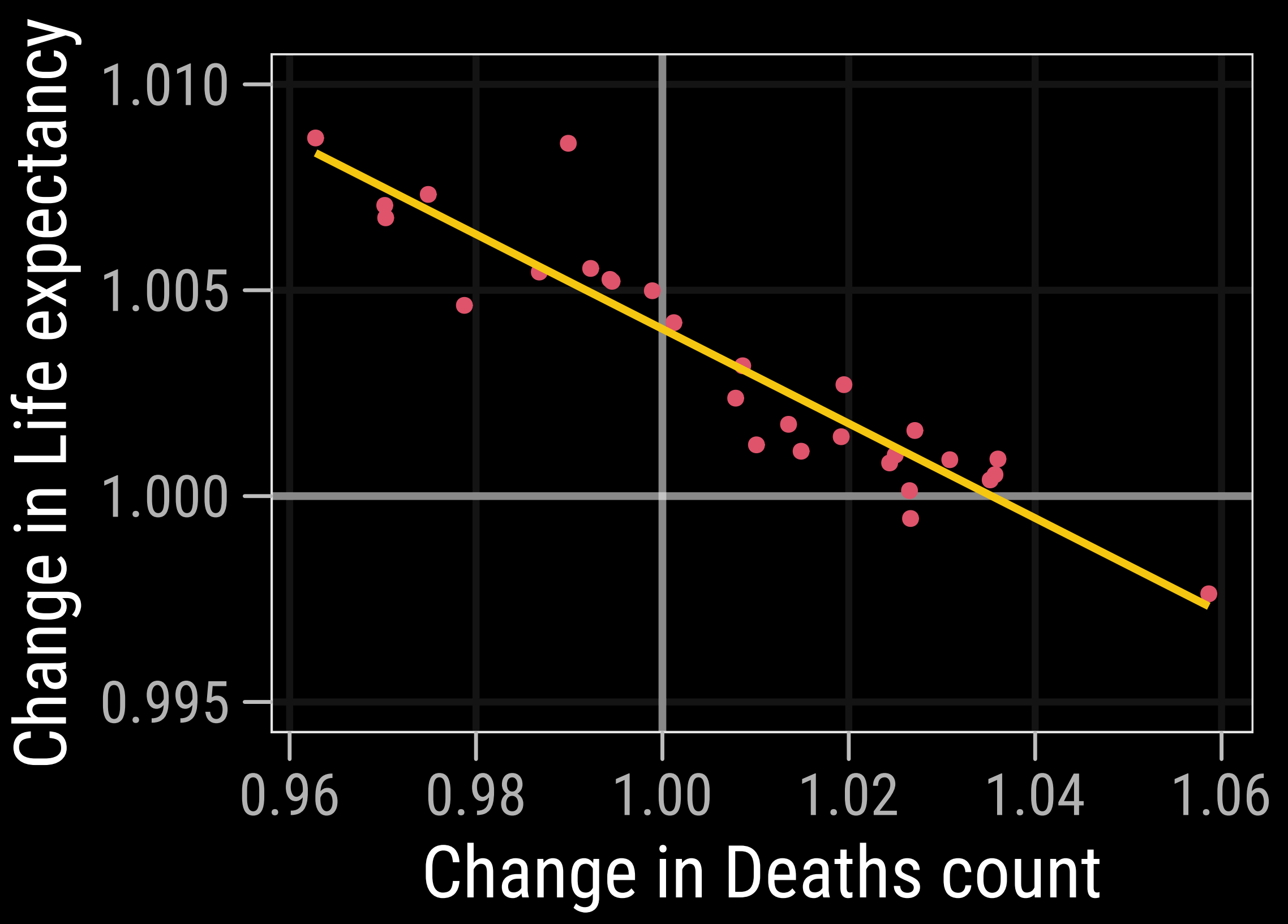




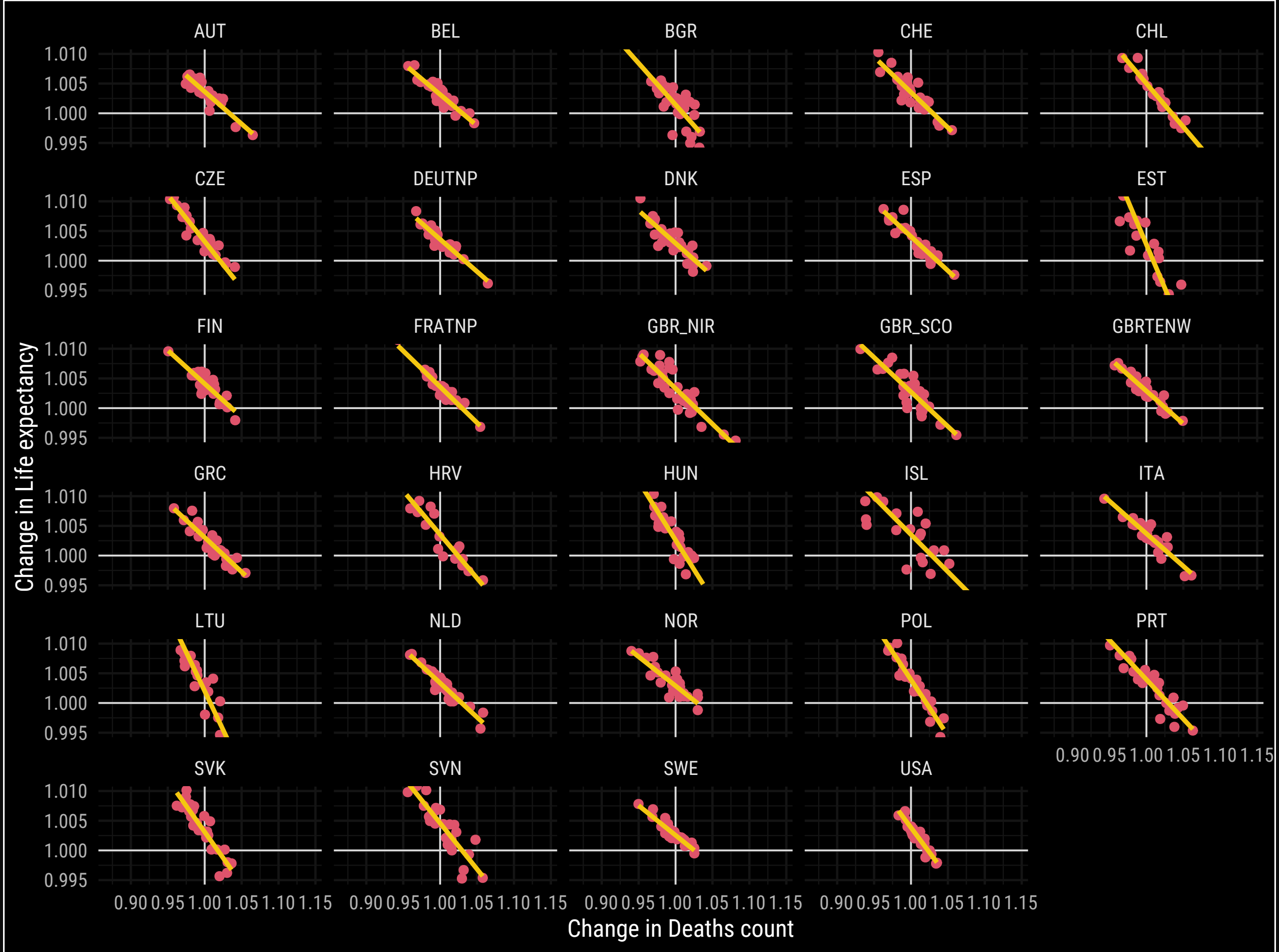




\section{What about 2020?}

\section{$\equiv$ GoogleTrends $\quad$ Explore}

- unprecedented Search term

Worldwide

2004 - present $\checkmark$

All categories

Web Search -

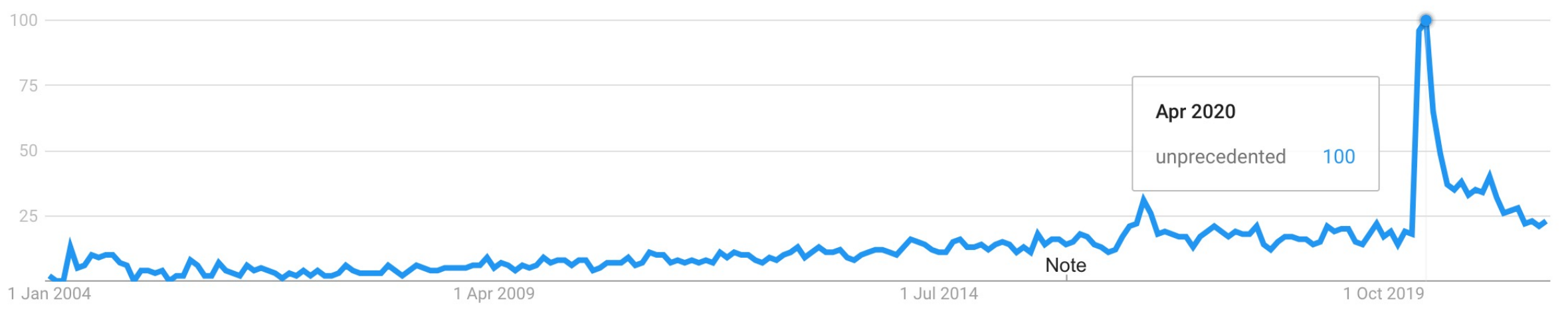


AUS

AUT

BEL
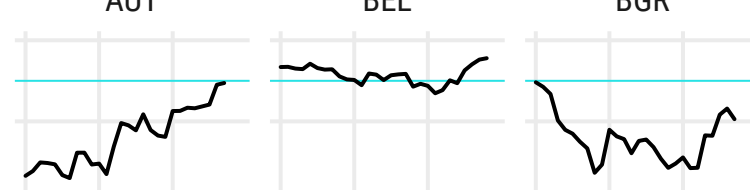

BLR

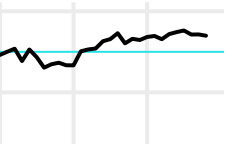

$r^{\text {CAN }}$

CHE

CHL

CZE

DEUTE 

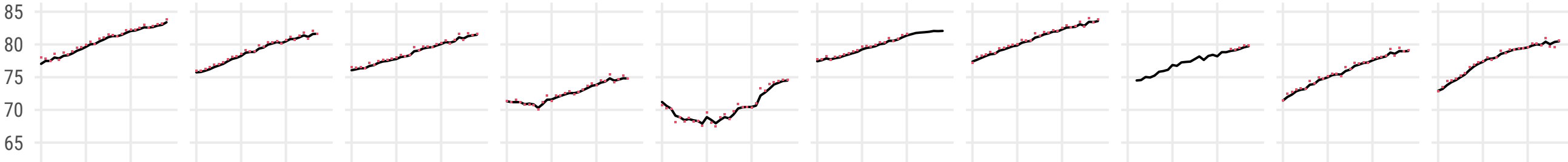

Are we

DEUTNP
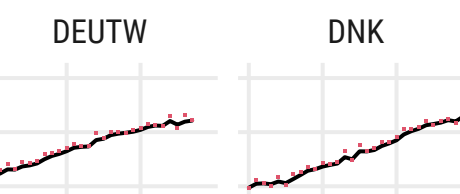

ESP
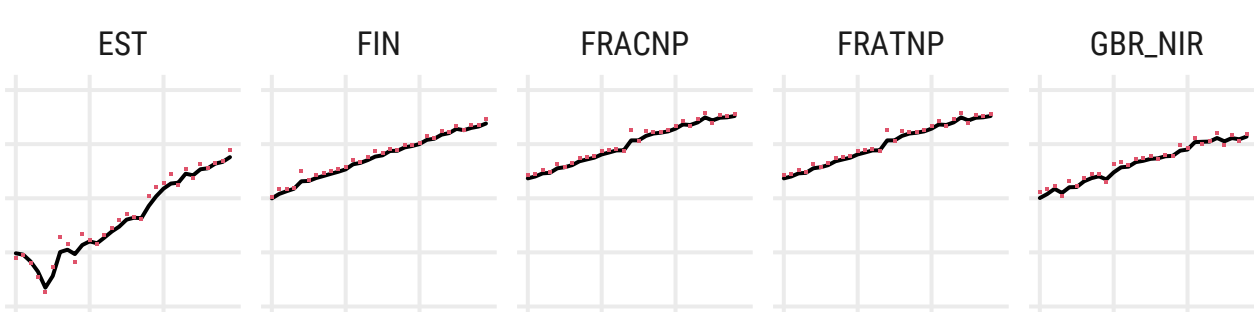

GBR_NP
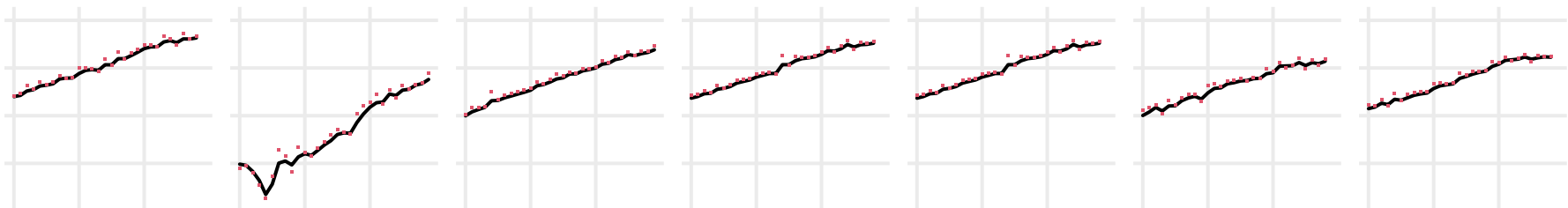
close?

GBR_SCO

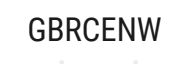

GBRTENW

GRC

HKG
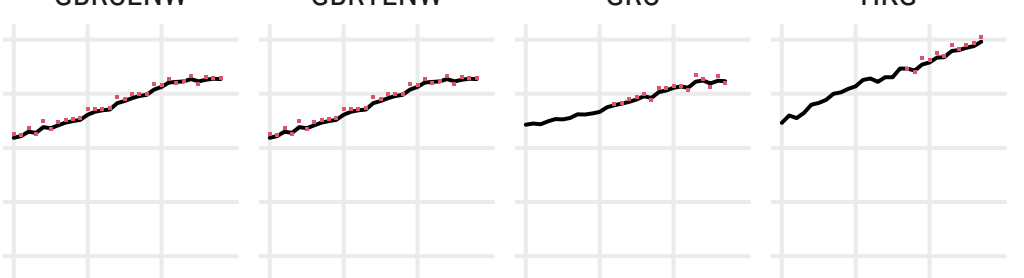

HRV

HUN

IRL

ISL

ISR
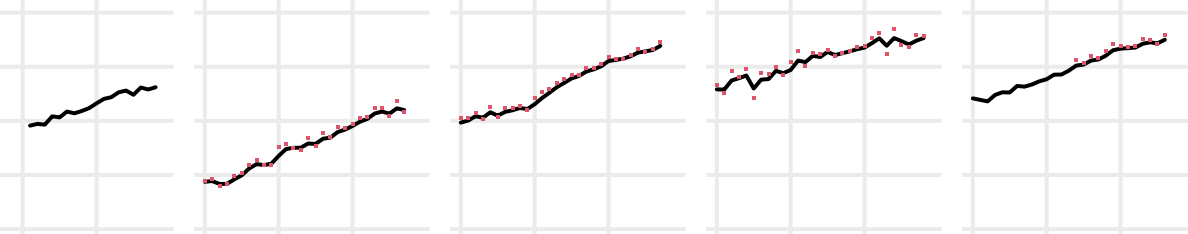

ITA

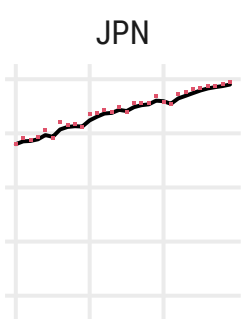

KOR

LTU

LUX
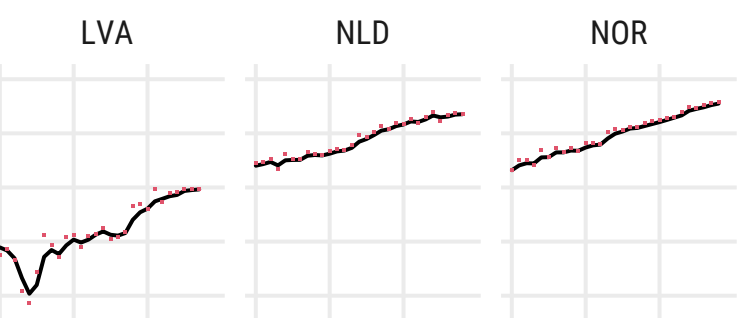

NZL_MA

NZL_NM
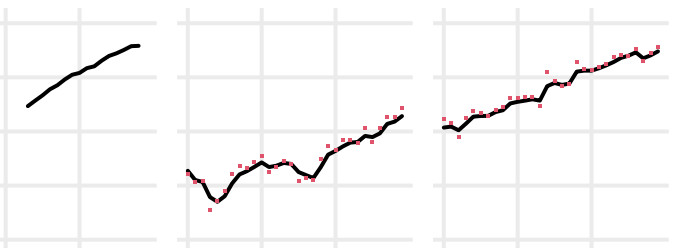

SVN
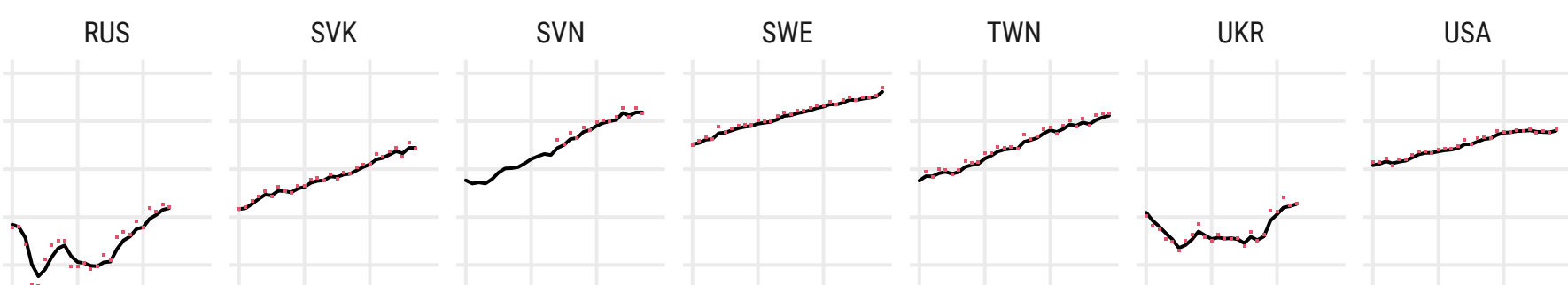

'90 $2000 \quad$ '10

'90 $2000 \quad 10$

$\begin{array}{lll}90 & 2000 & 10\end{array}$

$\begin{array}{lll}90 & 2000 \quad 10\end{array}$ 


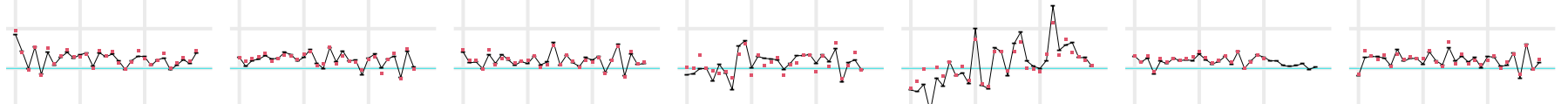

DEUTNP

DEUTW

DNK

ESP

EST

FIN

FRACNP

FRATNP

GBR_NIR

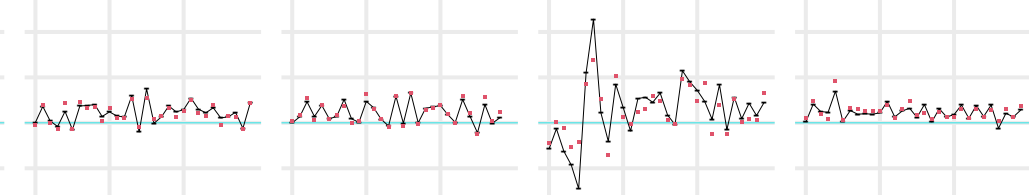

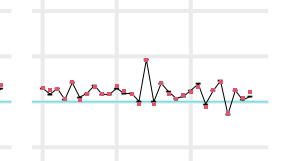

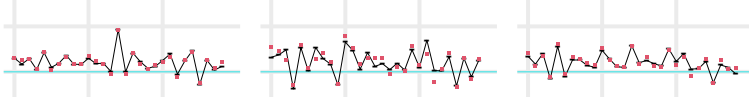

GBR_NP

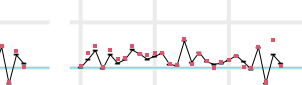

GBR_SCO

GBRCENW
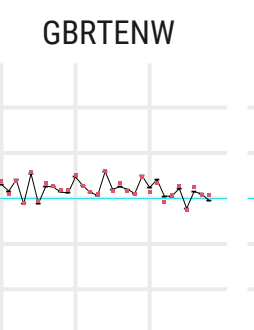

GRC

HKG

HRV

HUN

IRL

ISL

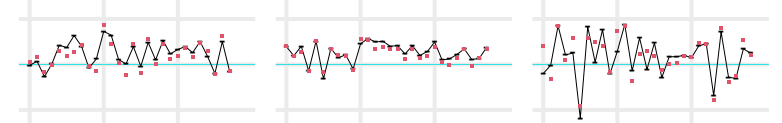

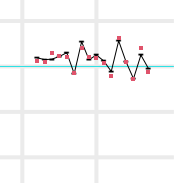
KOR

LTU

LUX

LVA

NLD

NOR

NZL_NM

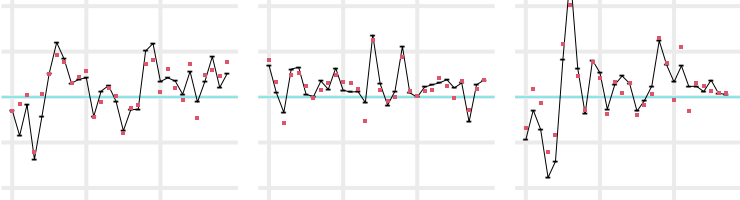

SVK

SVN

SWE

TWN

UKR

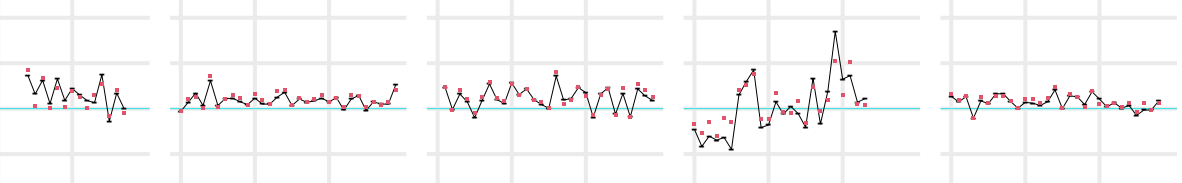

Absolvite changes and errors

ISR

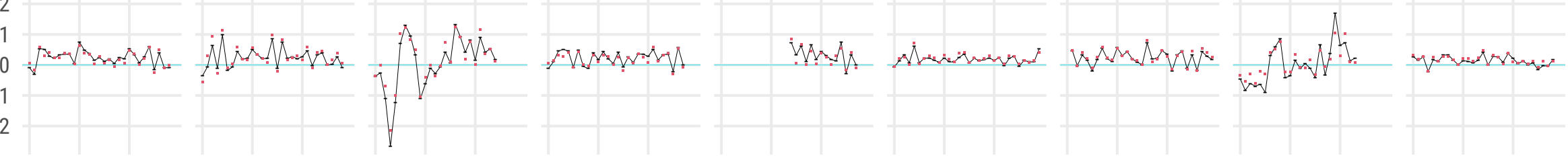

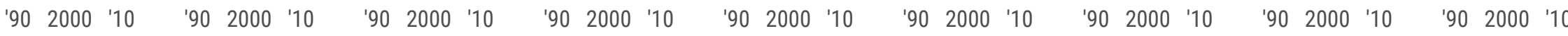




\section{Why does it work?}

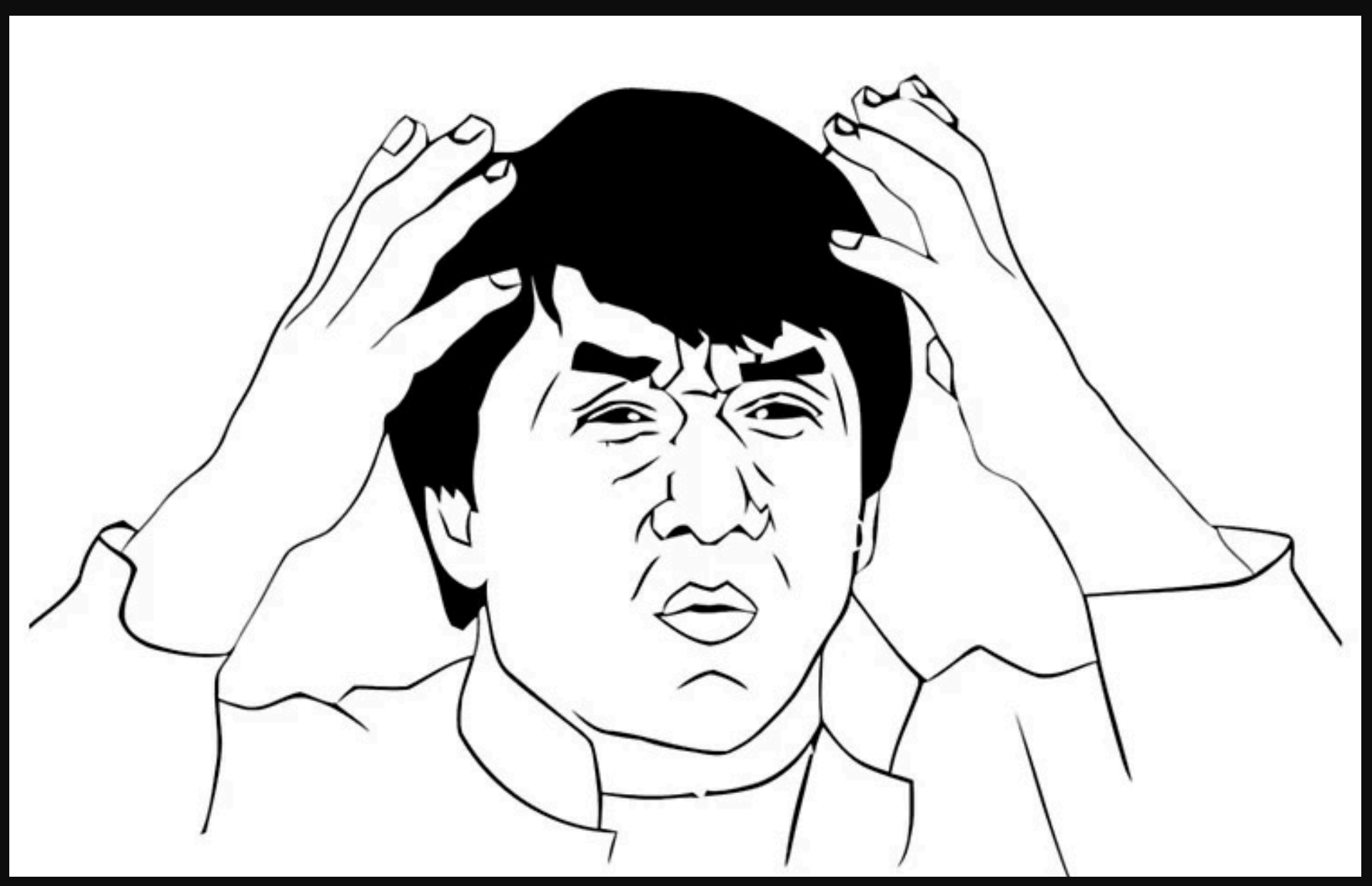




\section{Spain}

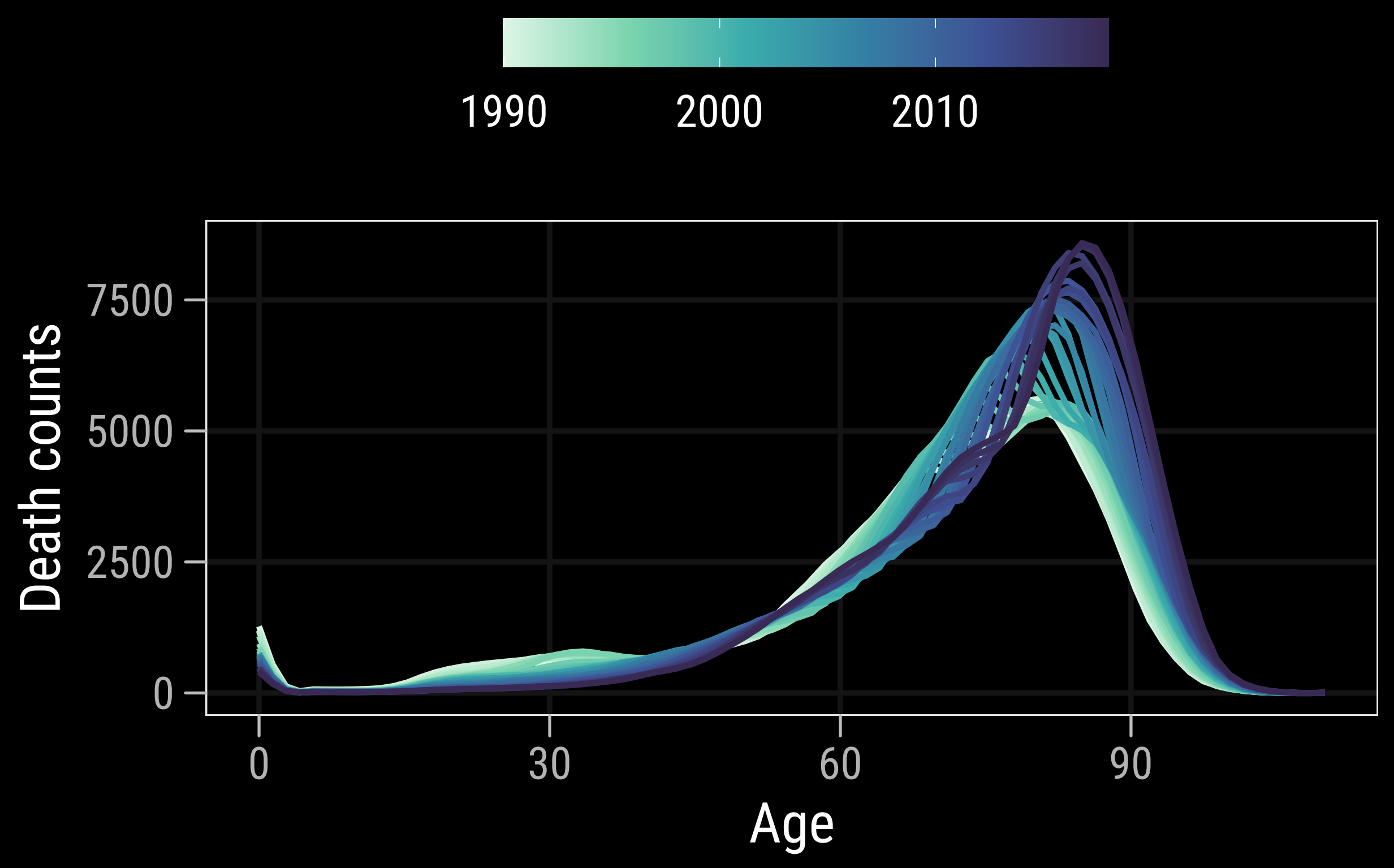




\section{Spain}

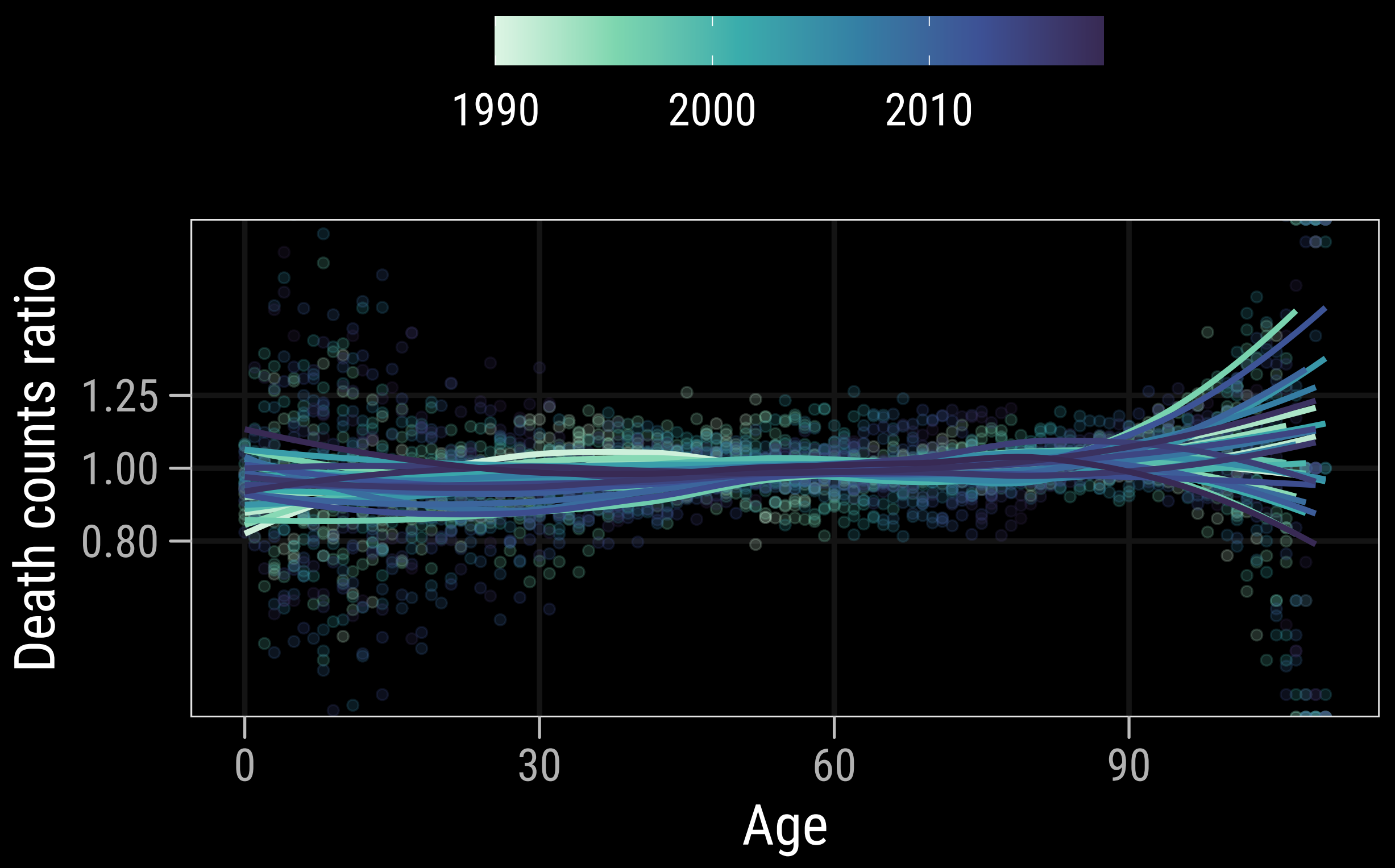




\section{Materials and Methods}

\section{Keyfitz's H}

doi.org/10.1073/pnas.2006392117

\section{Demographic perspectives on the mortality of COVID-19 and other epidemics}

Joshua R. Goldstein ${ }^{\mathrm{a}, 1}$ and Ronald D. Lee $\mathrm{L}^{\mathrm{a}, 1,2}$ (1)

a Department of Demography, University of California, Berkeley, CA 94720

Edited by Douglas S. Massey, Princeton University, Princeton, NJ, and approved July 31, 2020 (received for review April 7, 2020)

To put estimates of COVID-19 mortality into perspective, we estimate age-specific mortality for an epidemic claiming for illustrative purposes 1 million US lives, with results approximately scalable over a broad range of deaths. We calculate the impact on period life expectancy (down 2.94 y) and remaining life years (11.7 y per death). Avoiding 1.75 million deaths or 20.5 trillion person years of life lost would be valued at $\$ 10.2$ to $\$ 17.5$ trillion. The age patterns of COVID-19 mortality in other countries are quite similar and increase at rates close to each country's rate for all-cause mortality. The scenario of 1 million COVID-19 deaths is similar in scale to that of the decades-long HIV/AIDS and opioid-overdose epidemics but considerably smaller than that of the Spanish flu of 1918. Unlike HIVIAIDS and opioid epidemics, the COVID-19 deaths are concentrated in a period of months rather than spread out over decades.

COVID-19 | epidemic | mortality | demography | life expectancy
August 29 (1). The prospect of subsequent and afterward is uncertain. Earlier projections tality suggested that deaths could total mo if nothing were done to slow the spread 0 navirus (2). For illustrative purposes we us scenario of 1 million deaths in 2020 due dire across all waves, at times comparing it to a 250,000 and a higher one of 2 million. The $m$ scale approximately proportionately with the so readers can translate our results under $c$ scenarios.

The age pattern we use in this paper does nc rect increase in deaths as healthcare systems at the long-term effect of infection on the mortality of survivors. It also does not take into account any potential lowering of mortality, for example, from decreased air pollution, traffic accidents, and consumption of alcohol resulting from the economic slowdown. These effects may be important, but the age pattern of
Mathematical Models.

Keyfitz's result for life table entropy. Life expectancy at age $0 \mathrm{y}$ is computed as the sum of expected person years of survival of a newborn:

$$
e(0)=\int_{0}^{\omega} \ell(x) d x
$$

Survival $\ell(x)$ is given in terms of the hazard of death $m(a)$ as

$$
\ell(x)=e^{-\int_{0}^{x} m(a) d a} .
$$

A population subject to a new cause of mortality that increases death rates at all ages by $\Delta$, such that $m(x \mid \Delta)=m(x)(1+\Delta)$, will have life expectancy given by

$$
e(0 \mid \Delta)=\int \ell(x)^{1+\Delta} d x
$$

Differentiating the logarithm of life expectancy with respect to $\Delta$,

$$
\frac{d \log e(0 \mid \Delta)}{d \Delta}=\frac{\int \log \ell(x) \ell(x)^{1+\Delta} d x}{\int \log \ell(x)^{1+\Delta} d x} .
$$

At $\Delta=0$, this simplifies to

$$
\left.\frac{d \log e(0 \mid \Delta)}{d \Delta}\right|_{\Delta=0}=\frac{\int \log \ell(x) \ell(x) d x}{e(0)} .
$$

Keyfitz defines $H$ as $-\int \log \ell(x) \ell(x) d x / e(0)$. Some further manipulation gives us the form for $H$ in terms of remaining life expectancy:

$$
H=\frac{\int d(x) e(x) d x}{e(0)}
$$

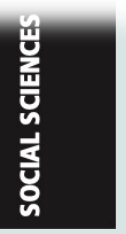




\section{Thank you!}

\section{Ilya Kashnitsky}

ikashnitsky@sdu.dk @ikashnitsky 